\title{
A serious conundrum for surgeons: Stump appendicitis
}

\author{
Mehmet Fatih Ekici, ${ }^{1}$ Zulfu Bayhan, ${ }^{2}$ Sezgin Zeren, ${ }^{2}$ Bercis Imge Ucar, ${ }^{2}$ \\ Mehmet Korkmaz, ${ }^{2}$ Ayse Nur Deger ${ }^{4}$ \\ ${ }^{1}$ Department of General Surgery, Evliya Celebi Training and Research Hospital, Kutahya, Turkey \\ ${ }^{2}$ Faculty of Medicine, Department of General Surgery, Dumlupınar University, Kutahya, Turkey \\ ${ }^{3}$ Faculty of Medicine, Department of Radiology, Dumlupınar University, Kutahya, Turkey \\ ${ }^{4}$ Faculty of Medicine, Department of Pathology, Dumlupınar University, Kutahya, Turkey
}

\begin{abstract}
Stump appendicitis is an acute inflammation of remnant appendix, a rare complication of incomplete appendectomy. It may present as acute abdomen with history of appendectomy, which may cause delay in diagnosis. Therefore, incomplete appendectomy should be considered as a differential diagnosis of acute abdomen in patients with medical history of appendectomy. The present case is one of stump appendicitis 6 months after appendectomy. Stump appendectomy was performed and the patient was discharged 7 days after the operation without any complication.

Keywords: Acute abdomen; delayed surgery; stump appendicitis.
\end{abstract}

\begin{abstract}
A ppendectomy is the most common emergency surgical intervention in abdominal surgery. Stump appendicitis is a rare condition characterized by inflammation of the remnant appendix tissue left behind after appendectomy, first published by Rose in $1945[1,2]$. The stump may pose a serious diagnostic conundrum if the surgeon is unaware of this uncommon phenomenon. A history of appendectomy can cause delay in diagnosis and may increase morbidity [2].
\end{abstract}

\section{CASE REPORT}

A 26-year-old man was admitted to the emergency department with a 24-hour history of diffuse ab- dominal pain that had started in the epigastric area, then localized at the right lower quadrant (RLQ), followed by nausea and vomiting.

Six months earlier, he had undergone an open appendectomy due to appendicitis. Physical examination revealed a McBurney incision scar. Tenderness and rebound tenderness were noted in the RLQ during palpation. White blood cell (WBC) count was 17400 cells $/ \mathrm{mm}^{3}$ with a neutrophil percentage of $78 \%$, whereas $\mathrm{C}$-reactive protein (CRP) was in normal reference ranges. Contrast-enhanced computed tomography (CECT) scan of abdomen and pelvis showed pericecal free pelvic fluid, cecal inflammation and inflammatory changes in the

Received: 18.08.2015 Accepted: 24.01.2016 Online: 04.04.2016

Correspondence: Dr. Mehmet Fatih EKICI. Genel Cerrahi Klinigi, Evliya Celebi Egitim Arastirma Hastanesi, 43000 Kutahya, Turkey.

Tel: +90 2747423166 e-mail: mfatihekici@gmail.com

(c) Copyright 2016 by Istanbul Northern Anatolian Association of Public Hospitals - Available online at www.kuzeyklinikleri.com 


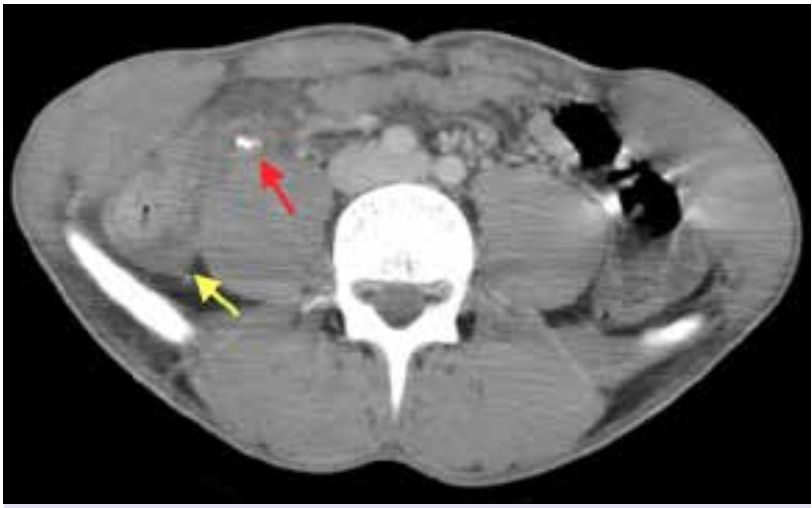

FIGURE 1. Yellow arrow: Periceceal free pelvic fluid, cecal inflammation; red arrow: Right lower quadrant with a dilated tubular structure (stump appendicitis).

RLQ with a dilated tubular structure extending from the base of the cecum (Figure 1).

The patient underwent emergency surgery for acute abdomen. Laparotomy was performed through lower midline incision. Purulent fluid and severe adhesions in the right iliac fossa were observed. After adhesiolysis, a remnant suppurative appendiceal stump $5 \mathrm{~cm}$. in size was noted. The appendicular stump had not been inverted in the previous surgery. Stump appendectomy was performed. The postoperative period was uneventful and the patient was discharged on the seventh post-

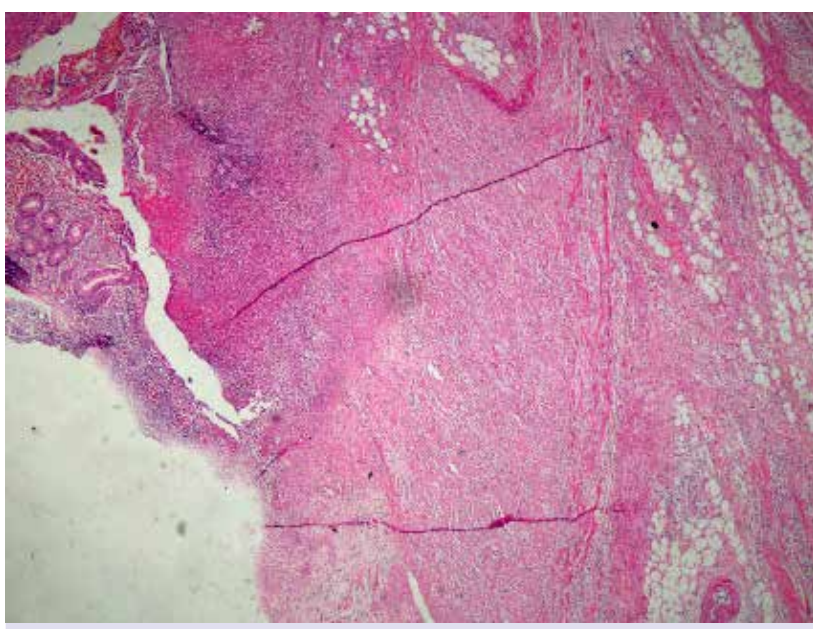

FIGURE 2. On surface epithelium ulceration, all the layers of appendix wall leukocyte infiltration (Hematoxylin and Eosin $\times 100$ ). operative day. Histopathological examination confirmed stump appendix $5 \mathrm{~cm}$ in size with features of local peritonitis (Figure 2).

\section{DISCUSSION}

Most patients diagnosed with stump appendicitis present with typical symptoms and findings of acute appendicitis, including pain that starts periumbilically and migrates to the RLQ with anorexia, nausea and vomiting [3]. Leukocyte count and CRP levels are usually found to be elevated. Tomography scan is more useful than ultrasound to diagnose stump appendicitis, as ultrasonographic findings are not characteristic $[2,4]$. CECT scan can reveal findings that support the diagnosis of stump appendicitis, such as inflammatory changes in pericecal region, thickening of cecal wall, abscess formation, presence of fluid in right paracolic area, and air-filled tubular structure $[5,6]$. Tomography scan not only confirms stump appendicitis but also excludes other differential diagnoses [4].

Clinical diagnosis of stump appendicitis may be difficult due to underlying conditions like mental retardation, pregnancy, immune suppression and steroid use. Medical history of appendectomy can also lead to delay or even missed diagnosis of stump appendicitis. Therefore, stump appendicitis should be considered in differential diagnosis of patients with acute abdomen indication, appendectomy or McBurney's incision scar [7].

Cecal diverticulitis should also be considered in differential diagnosis of stump appendicitis since cecal diverticulitis is clinically indistinguishable from acute appendicitis. It has been reported that almost $70 \%$ of patients with cecal diverticulitis underwent surgery based on preoperative diagnosis of acute appendicitis, and correct preoperative diagnosis was made in only $5.3 \%$ of 318 patients [8]. It is also reported that time interval from initial appendectomy to stump appendectomy may vary from 2 months to 50 years $[1,9]$. In the present case, stump appendicitis developed 6 months after first appendectomy.

Rate of perforation for stump appendicitis (detected during surgery) approaches $68 \%$ and length of hospital stay increases due to delayed diagnosis 
[2]. Stump length varied between 0.5 and $5.1 \mathrm{~cm}$ in patients diagnosed with stump appendicitis. Appropriate stump length to be left after appendecto$\mathrm{my}$ is $3-5 \mathrm{~mm}$ to prevent stump appendicitis [10].

Incidence and prevalence of stump appendicitis have increased in recent years. Stump appendicitis has been reported after both open and laparoscopic appendectomy; there is very little difference between various surgical techniques in terms of increase in incidence of stump appendicitis [11]. In both open and laparoscopic appendectomy, optimal visualization of base of appendix is necessary to minimize incidence of stump appendicitis. A longer stump can be obstructed with fecalith, which may lead to chronic inflammation causing ischemia of appendiceal wall and eventually perforate and/or suppurate [12]. While some authors do not support this idea, incidence of stump appendicitis has increased relative to the increase of laparoscopic appendectomy [13]. In an open or laparoscopic approach, careful appendix artery dissection of taenia coli reduces possibility of leaving a long stump. Appendiceal cecal junction identification is very important, especially for subserous appendix [14]. In the present case, retrospective examination of patient's medical records of first appendectomy revealed multiple abscesses and adhesions in right iliac fossa (RIF). Simple ligation was performed.

It is important to understand that a history of appendectomy is, by itself, insufficient to exclude diagnosis of appendicitis. Presence of McBurney scar may be a warning for surgeons to consider stump appendicitis during an emergency examination. Identification of appendiceal base by tracing taenia coli to appendix is very important to prevent stump appendicitis. Appendiceal stump of less than $5 \mathrm{~mm}$ in length can minimize incidence of stump appendicitis. Careful evaluation of clinical and computed tomography (CT) scan findings may prevent delay in diagnosis, and decrease morbidity and length of hospital stay.
Conflict of Interest: None declared.

Financial Disclosure: The authors declared that this study has received no financial support.

Authorship contributions: Concept - M.F.E., Z.B.; Design - M.F.E., S.Z.; Supervision - M.K., B.I.U.; Data collection M.F.E., A.N.D.; Analysis - S.Z., Z.B.; Literature search - M.F.E., B.I.U.; Writing - M.F.E., S.Z.; Critical review - M.K., A.N.D.

\section{REFERENCES}

1. Aydın A, Buluş H, Yavuz A, Akkoca M, Coşkun A. A rare case report: Stump appendicitis. Turkish J. Surg 2012;28:156-8.

2. Önder A, Kapan M, Böyük A, et al. Stump Appendicitis After Appendectomy. Turkish Dis Col and Rec 2010;20:188-91.

3. Roberts KE, Starker LF, Duffy AJ, Bell RL, Bokhari J. Stump appendicitis: a surgeon's dilemma. JSLS 2011;15:373-8. Crossre.

4. Uludag M, Isgor A, Basak M. Stump appendicitis is a rare delayed complication of appendectomy: A case report. World J Gastroenterol 2006;12:5401-3. Crossre.

5. Sharma M, Agrawal A. Pictorial essay: CT scan of appendicitis and its mimics causing right lower quadrant pain. Indian J Radiol Imaging 2008;18:80-9. Crossre

6. Truty MJ, Stulak JM, Utter PA, Solberg JJ, Degnim AC. Appendicitis after appendectomy. Arch Surg 2008;143:413-5. Crossre.

7. Menteş O, Zeybek N, Oysul A, Onder SC, Tufan T. Stump appendicitis, rare complication after appendectomy: report of a case. Ulus Travma Acil Cerrahi Derg 2008;14:330-2.

8. Lane JS, Sarkar R, Schmit PJ, Chandler CF, Thompson JE Jr. Surgical approach to cecal diverticulitis. J Am Coll Surg 1999;188:629-35. Crossre

9. Salehi H, Anjamrooz SH. Successfully treated stump appendicitis diagnosed by CT and ultrasonography. Indian J Surg 2008;70:89-91. Crossret

10. Erzurum VZ, Kasirajan K, Hashmi M. Stump appendicitis: a case report. J Laparoendosc Adv Surg Tech A 1997;7:389-91.

11. Kumar A, Sharma A, Khullar R, Soni V, Baijal M, Chowbey PK. Stump appendicitis: A rare clinical entity. J Minim Access Surg 2013;9:173-6.

12. Özden İ, Özkan E. Internal herniation due to a long appendiceal stump. J Istanbul Med Fac 2000;63:80-1.

13. Awe JA, Soliman AM, Gourdie RW. Stump appendicitis: an uncompleted surgery, a rare but important entity with potential problems. Case Rep Surg 2013;2013:972596. Crossree

14. Constantin V, Popa F, Carâp A, Socea B. Stump appendicitis an overlooked clinical entity. Chirurgia (Bucur) 2014;109:12831. 